\title{
FASTER CHITOSAN PRODUCTION BY MUCORALEAN STRAINS IN SUBMERGED CULTURE
}

\author{
Rosa Valéria da Silva Amorim'; Wanderley de Souza²; \\ Kazutaka Fukushima ${ }^{3}$; Galba Maria de Campos-Takaki* \\ ${ }^{1}$ Laboratório de Imunopatologia Keizo Asami/LIKA, Universidade Federal de Pernambuco, Recife, PE, Brasil. \\ ${ }^{2}$ Instituto de Biofísica, Universidade Federal do Rio de Janeiro, Rio de Janeiro, RJ, Brasil. \\ ${ }^{3}$ Research Center for Pathogenic Fungi and Microbial Toxicoses, Chiba University, Inohana, Chuo-Ku, Chiba, Japan. \\ ${ }^{4}$ Núcleo de Pesquisas em Ciências Ambientais, Departamento de Química, Universidade Católica de Pernambuco, Recife, PE, Brasil. \\ Submitted: June 26, 2000; Returned to authors for corrections: September 14, 2000; Approved: November 14, 2000

\begin{abstract}
Production of chitosan was conducted using two Mucoralean strains, Mucor racemosus and Cunninghamella elegans. Chitosan was extracted from mycelia of $M$. racemosus and $C$. elegans at different growth phases on YPD medium. In both fungi, chitosan was rapidly produced, while highest yield of extractable chitosan was found in $24 \mathrm{~h}$ of cultivation in submerged culture. The yield of chitosan isolated from dry mycelia of $M$. racemosus was about $40 \%$ higher than from C. elegans. The degree of $N$-acetylation of chitosan was $49 \%$ in M. racemosus and $20 \%$ in C. elegans, and the D-glucosamine contents were about $48 \%$ and $90 \%$, respectively.
\end{abstract}

Key words: Chitosan, submerged culture, Mucor racemosus, Cunninghamella elegans

\section{INTRODUCTION}

Chitosan is a natural polymer derived from chitin, the principal fiber component of the exoskeleton of shellfish. It is a polysaccharide formed primarily by repeated units of $\beta(1-4) 2-$ amino-2-deoxy-D-glucose (or D-glucosamine). Chitosan can be also found in the majority of Mucoralean fungi (Zygomycetes) $(15,16)$. In Mucor rouxii it is the principal fiber polymer of the cell wall in addition to chitin (2). It has been isolated from Absidia coerulea $(5,8)$ and other Mucoraceae strains (14). Chitosan in cell walls is produced through enzymatic deacetylation of chitin. $\mathrm{N}$-deacetylation is a common step in the modification of sugar chains, which may confer resistance to lysozyme action (10). Chitosan has great potential in agriculture, medicine, biotechnology and pharmaceutical industries. The development of applications for chitosan in drug delivery has expanded rapidly in recent years $(6,12,17)$. The process of producing commercial chitosan involves several steps, such as, taking the shells of crustaceans, grinding them to a fine powder and deacetylating this powder using strong alkali (1). This chemical approach appears to have a limited potential in production of chitosan for medical applications due to the inappropriate physicochemical properties. Therefore, the use of Zygomycetes mycelia has been proposed as a good alternative source of chitosan. In this work a comparative study of chitosan produced by Mucor racemosus and Cunninghamella elegans related to cell growth and physical chemical properties was carried out.

\section{MATERIALS AND METHODS}

\section{Microorganisms and culture conditions}

Mucor racemosus IFM 40781 and Cunninghamella elegans URM 46109 were maintained at $4^{\circ} \mathrm{C}$ on potato dextrose agar slants. The submerged cultures were carried out in Erlenmeyer flasks of $250 \mathrm{ml}$ of capacity, containing $50 \mathrm{ml}$ of YPD medium ( $0.3 \%$ yeast extract, $1 \%$ polypeptone and $2 \%$ D-Glucose $\mathrm{pH}$ adjusted to 4.5) (2), inoculated with $10^{5}$ spores $/ \mathrm{ml}$ (final concentration), grown on rotary shaker $(100 \mathrm{rpm})$ at $28^{\circ} \mathrm{C}$ for 96

\footnotetext{
* Corresponding author. Mailing address: Núcleo de Pesquisa em Ciências Ambientais, Departamento de Química, Universidade Católica de Pernambuco, Rua do Príncipe, 526, Boa Vista, CEP 50050-901, Recife, PE, Brasil. Fax: (+5581) 216-4004. E-mail: takaki@unicap.br
} 
hours. The experiments were made in duplicate. Samples (50 $\mathrm{ml}$ ) were collected in 24 hours intervals for biomass determination using thermogravimetric analysis and for chitosan extraction. Filtrates were used for $\mathrm{pH}$ determination and D-glucose consumption measurements (enzymatic method - glucose oxidase, BIOCLIN).

\section{Chitosan extraction and analyses}

Mycelia from both fungi harvested by vacuum filtration, washed with distilled water and freeze-dried. Chitosan extraction was a simplified version of the procedure carried out by White et al. (18). The dry mycelia were homogenized and deproteinized with $\mathrm{NaOH} 1 \mathrm{M}$ in $95 \%$ ethanol $(1: 2)$ at $100^{\circ} \mathrm{C}$ for 90 minutes. $\mathrm{HCl} 1 \mathrm{M}$ was added to the precipitate at $95^{\circ} \mathrm{C}$ for $5 \mathrm{~h}$. The $\mathrm{pH}$ was adjusted to 8.5 with $1 \mathrm{M} \mathrm{NaOH}$ to precipitate chitosan.

The IR spectra of chitosan were carried out using the $\mathrm{KBr}$ disc method in a Bruker IFS 66 spectrometer. Based on the infrared spectrum the degree of acetylation (DA) was determined according to Roberts (13), using the absorbance ratio $\mathrm{A}_{1655} / \mathrm{A}_{3450}$ and calculated according to the following equation:

$$
\mathrm{A}(\%)=\left(\mathrm{A}_{1655} / \mathrm{A}_{3450}\right) \times 100 / 1.33
$$

Spectrophotometric measurements of D-glucosamine residues in chitosan extracted from fungi were analysed. Samples (10 $\mathrm{mg}$ ) of chitosan were hydrolysed with hydrochloric acid $(\mathrm{HCl})$ $4 \mathrm{M}$ for $12 \mathrm{~h}$ at $90^{\circ} \mathrm{C}$, and the content of D-glucosamine estimated at $530 \mathrm{~nm}$ as described (3).

\section{RESULTS AND DISCUSSION}

Under submerged culture, for both fungi the maximum chitosan yield from mycelia mass was obtained early in the growth phase. Within 24h, Mucor racemosus produced a chitosan yield of $35.1 \mathrm{mg} / \mathrm{g}$ dry mycelia weight and Cunninghamella elegans $20.5 \mathrm{mg} / \mathrm{g}$ dry mycelia weight (Figs. 1 and 2). The growth curves of filamentous fungi $M$. racemosus and C. elegans were similar, particularly in the exponential phase. However, the hyphae grew only at the tips, so not all hyphae length contributed to growth. Both fungi presented diauxie growth. This effect was suggested by glucose source that induced the synthesis of enzymes required for its utilization. At the same time, this effect repressed the synthesis of enzymes required for yeast extract utilization. This effect stopped when all glucose source has been metabolised, within $50 \mathrm{~h}$ of growth.

By the end of growth, the biomass (dry weight) of $C$. elegans and $M$. racemosus were $2.5 \mathrm{~g} / 100 \mathrm{ml}$ and $1.5 \mathrm{~g} / 100 \mathrm{ml}$, respectively. However, chitosan production did not increase further with biomass.

The decline of the extractable chitosan after $24 \mathrm{~h}$, as shown in Fig. 1, could be due to physiological changes in the fungal

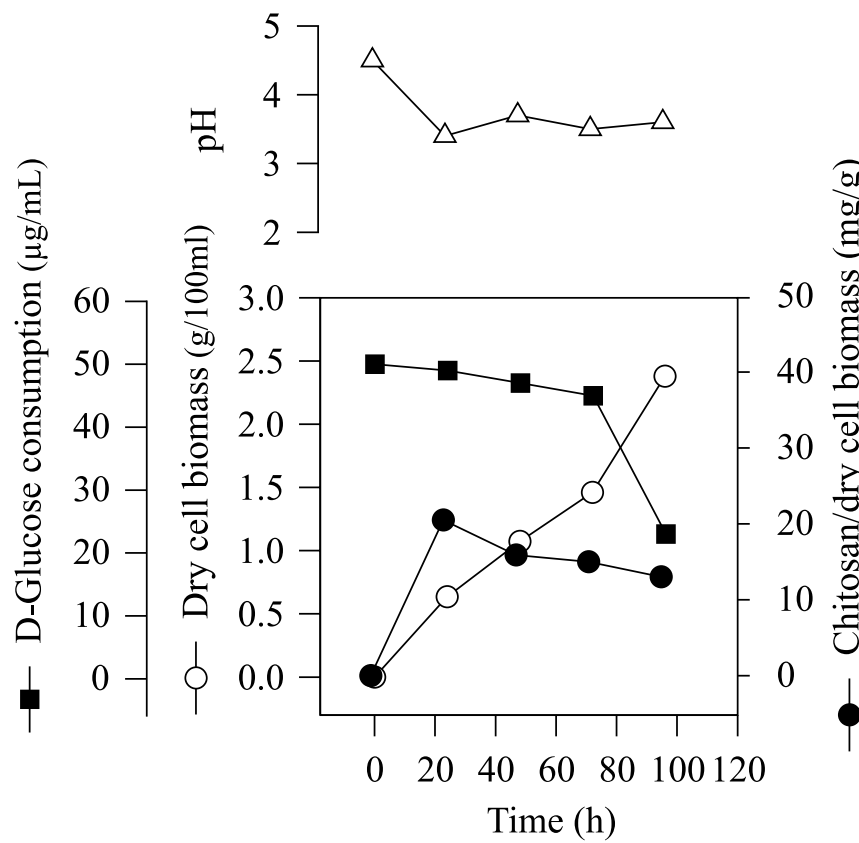

Figure 1. Cunninghamella elegans grown in submerged culture at $28^{\circ} \mathrm{C}$ using YPD medium.

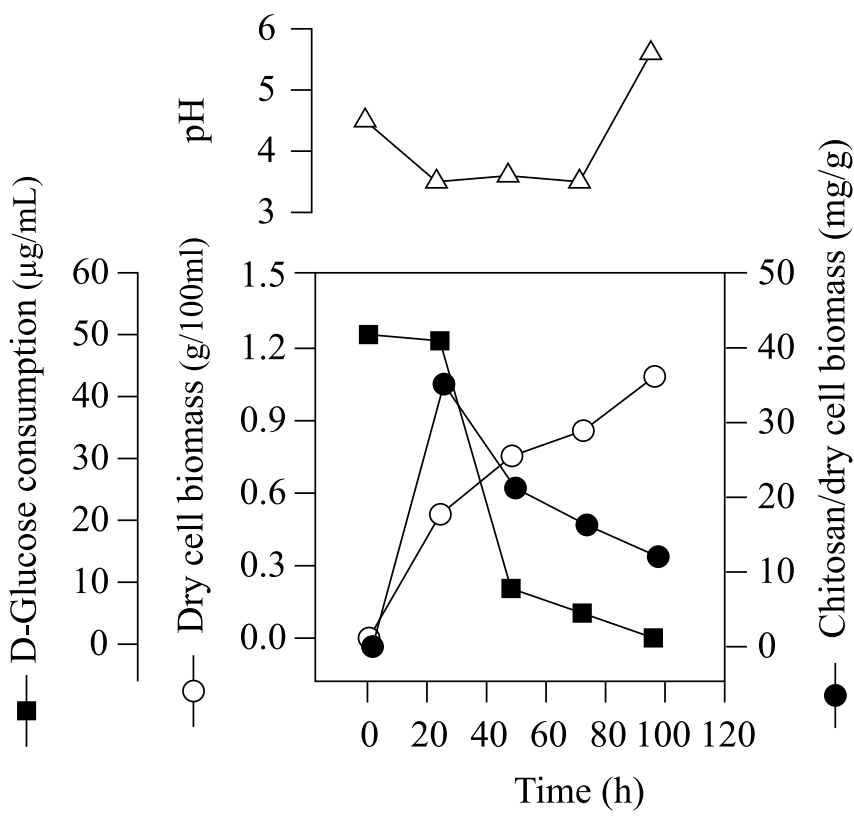

Figure 2. Mucor racemosum grown in submerged culture at $28^{\circ} \mathrm{C}$ using YPD medium.

cell wall. Higher chitosan yields in initial growth stages suggest that the chitosan formed by chitin deacetylase prevailed in these stages. It may be possible that during initial growth chitin is less crystalline and thus more susceptible to this enzyme (4). 
In $M$. rouxii, White et al. (18) reported chitosan yields ranging from 6 to $9 \%$ of the dry mycelia weight, using $12 \mathrm{~h}$ of extraction period with hydrochloric acid. In our results, the maximum yields reached $3.5 \%$ and $2.0 \%$ of the dry cell weight for $M$. racemosus and C. elegans, respectively, using only $5 \mathrm{~h}$ for chitosan extraction. Tan et al. (16) studied different Zygomycetes strains and observed that Cunninghamella echinulata was the best chitosan producing strain among all fungi, with a yield of approximately $7.0 \%$ of chitosan per mycelia dry weight.

During growth of both fungi the $\mathrm{pH}$ of the media drops in the first 24h, stowing high metabolic interchange between the medium substrate uptake and the release of ions from the cells. Furthermore, in Mucor racemosus the $\mathrm{pH}$ reached 5.6 in the last hours of cultivation. Higher yields of chitosan were found within 24 hours of cultivation of both fungi at $\mathrm{pH} 3.5$, which seems to be also a stimulating agent for production of this biopolymer (Figs. 1 and 2). In addition, Rane and Hoover (11) reported that the $\mathrm{pH}$ of the culture influenced the yield and the degree of $\mathrm{N}$ acetylation of chitosan from Absidia coerulea, probably due to the optimum $\mathrm{pH}$ of the chitin deacetylase, enzyme that converts chitin to chitosan in fungal cell wall. According to Kafetzopoulos et al. (7), optimum $\mathrm{pH}$ for chitin deacetylase activity from Mucor rouxii is $\mathrm{pH} 4.5$. The data in the present work are in agreement with Miyoshi et al. (9), i.e. the chitosan production by the microorganisms is strongly dependent of the culture conditions, including cultivation time.

\section{Chitosan analysis}

In this study, the fungi fractions were analysed by IR spectrophotometry. Based on the spectrum the $\mathrm{N}$-acetylation degree of the cell wall chitosan was estimated, as described by Roberts (13). The profiles of infrared spectrum of the insoluble fractions extracted from cell walls were quite similar to those presented by commercial chitosan (Sigma) (Fig 3). The peaks at $2300 \mathrm{~cm}^{-1}$ in Figs. $3 \mathrm{~b}$ and $2 \mathrm{c}$ were due to $\mathrm{CO}_{2}$ interference. The degree of $\mathrm{N}$-acetylation, estimated based on the ratio between the absorbance of the amide II band at approximately $1655 \mathrm{~cm}^{-1}$ and the C-H band at $3450 \mathrm{~cm}^{-1}$, was found to be around $20 \%$ in C. elegans after $24 \mathrm{~h}$. However, $M$. racemosus presented a higher degree of $\mathrm{N}$-acetylation (49\%) after 24h. Similar degrees of N-acetylation for chitosan produced from shellfish chitin were reported (13). These results are in agreement with Miyoshi et al. (9) who reported $59 \%$ and $35 \%$ degrees of $\mathrm{N}$-acetylation for $M$. rouxii and $C$. blakesleeana, respectively.

Quantitative analysis of D-glucosamine from hydrolysis of chitosan from mycelia wall of $M$. racemosus and C. elegans were carried out by Blix method (3). The D-glucosamine contents are shown in Table 1. Yields varied from approximately 50 to $90 \%$ of the fungi fraction, according to the age of the culture. In C. elegans, the highest D-glucosamine content $(90.0 \%)$ was found

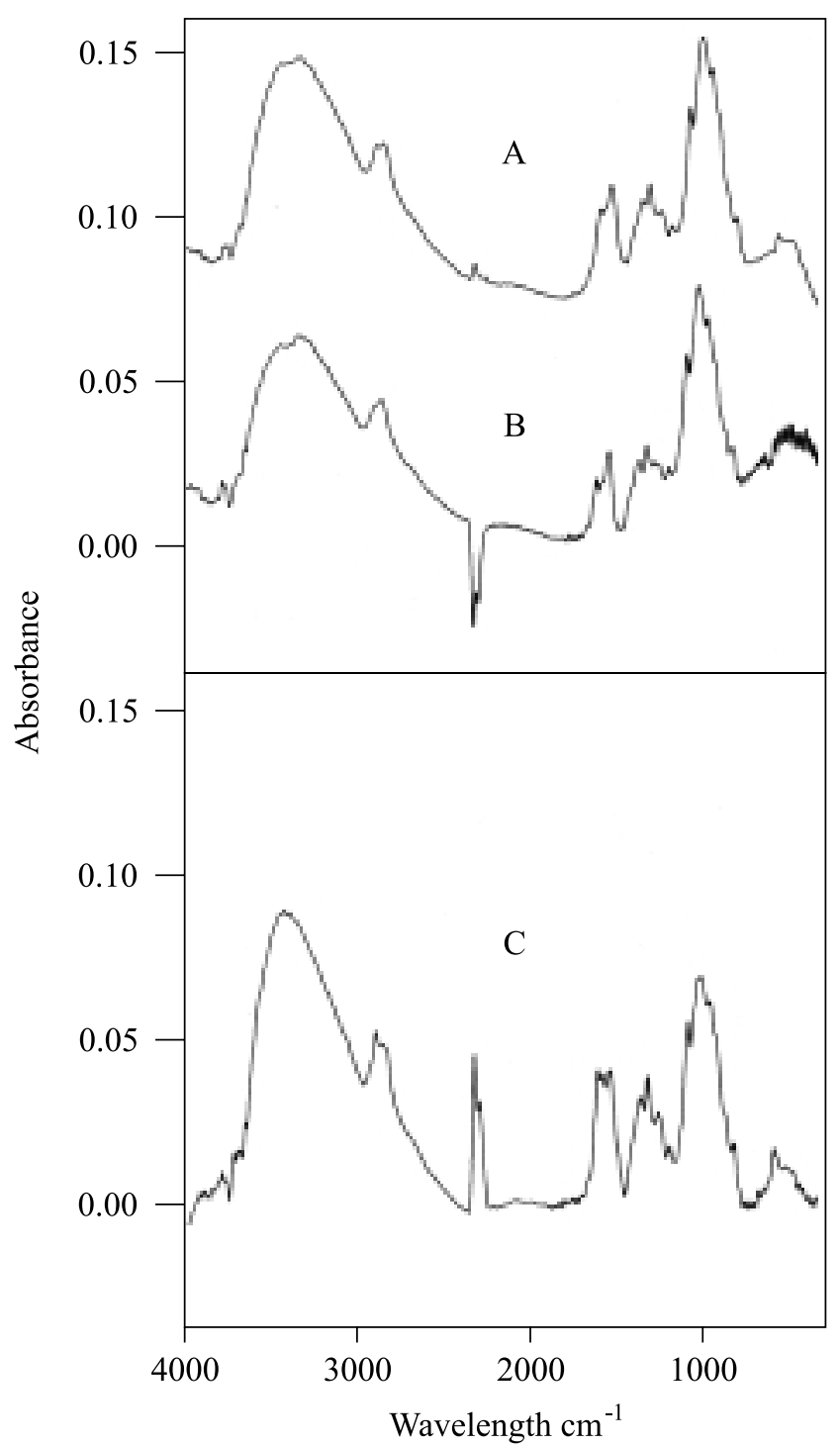

Figure 3. Infra red spectra of fungal chitosan from Mucor racemosum (A); Cunninghamella elegans (B) and commercial chitosan (Sigma) (C).

in 24h culture. Synowiecki (15) found that chitosan from Mucor rouxii contained $81.3 \%$ D-glucosamine and the degree of acetylation was $27.3 \%$. However, for M. racemosus, the Dglucosamine content was $58.0 \%$ in $24 \mathrm{~h}$ and degree of $\mathrm{N}$ Acetylation was $49 \%$.

Based on these results, we concluded that mycelium of Cunninghamella elegans is a good source of chitosan. The maximum production and the achievement of the desired physicochemical properties, such as same degree of acetylation found in chitosan extracted from crab shells, were obtained in $24 \mathrm{~h}$. Chitosan production from this fungus can be further optimised to improve yield in large-scale production. The 
Table 1. D-glucosamine contents of chitosan isolated from Mucor racemosus and Cunninghamella elegans grown in rotary shaker $(100 \mathrm{rpm})$ at $28^{\circ} \mathrm{C}$ using YPD medium (BartinickGarcia, 1968).

\begin{tabular}{cc}
\hline \multicolumn{1}{c}{ Fungi } & D-glucosamine (\%) \\
\hline Mucor racemosus & \\
24h & 57.5 \\
48h & 69.0 \\
$72 \mathrm{~h}$ & 49.0 \\
$96 \mathrm{~h}$ & 48.5 \\
Cunninghamella elegans & \\
24h & 90.5 \\
48h & 73.5 \\
$72 \mathrm{~h}$ & 77.0 \\
$96 \mathrm{~h}$ & 82.5 \\
\hline
\end{tabular}

conditions of extraction and processing (strength, time and acids) can also be optimised. Genetic manipulation of the fungal system in the near future may also increase the production of this important biopolymer.

\section{ACKNOWLEDGEMENTS}

The authors acknowledge the financial support of CAPES, FACEPE, PRONEX and CNPq. They are also grateful to William McDonald Ledingham for his critical reading of this manuscript.

\section{RESUMO}

\section{Rápida produção de quitosana por linhagens de Mucorales em cultura submersa}

A produção microbiológica da quitosana foi realizada usandose duas linhagens de Mucorales, Mucor racemosus and Cunninghamella elegans. Quitosana foi extraída a partir dos micélios de $M$. racemosus e $C$. elegans em diferentes fases de crescimento em meio YPD. Para ambos os fungos, quitosana foi rapidamente produzida, com rendimentos de quitosana mais elevados após $24 \mathrm{~h}$ de cultivo em cultura submersa. O rendimento de quitosana isolada a partir de micélio seco de $M$. racemosus foi cerca de $40 \%$ maior do que de C. elegans. O grau de $N$ - acetilação da quitosana foi $49 \%$ em M. racemosus e $20 \%$ em $C$. elegans, e os conteúdos de D-glicosamina foram cerca de 48 and $90 \%$, respectivamente.

Palavras-chave: quitosana, cultura submersa, Mucor racemosus, Cunninghamella elegans

\section{REFERENCES}

1. Austin, R.R.; Brine, C.J.; Castle J.E.; Zikakis, J.P. Chitin: New facets of research. Science 212: 744-753, 1981.

2. Bartinicki-Garcia, S. Cell wall chemistry morphogenesis and taxonomy of fungi. Ann. Rev. Microbiol. 22: 87-108, 1968.

3. Blix, G. The determination of hexosamines according to Elson and Morgan Acta. Chem. Scand. 2: 467, 1968.

4. Davis, L.L.; Bartinicki-Garcia, S. Chitosan synthesis by the tandem action of chitin synthetase and chitin deacetylase from M. rouxii Biochem. 23: 1065-1073, 1984.

5. Davoust, N.; Hansson, G. Identifying the conditions for development of beneficial mycelium morphology for chitosan-producing Absidia spp. in submersed cultures. Appl Microbiol Biotecnol. 36: 618-620, 1991.

6. Gupta, K.C.; Ravi Kumar, M.N. Drug release behavior of beads and microgranules of chitosan. Biomaterials. 21:1115-9, 2000.

7. Kafetzopoulos, D.; Martinou, A.; Bouriotis, V. Bioconversion of Chitin to Chitosan: Purification and Characterization of chitin deacetylase from Mucor rouxii. Proc. Natl. Acad. Sci, USA, 90: 2564-2568, 1993.

8. McGahren, W.J.; Perkinson,G.A.; Growich, J.A.; Leese, R.A.; Ellestad, G.A. Chitosan by Fermentation. Process Biochemistry, 19: 88-90, 1984.

9. Miyoshi, H.; Shimura, K.; Watanabe, K.; Onodera, K. Characterization of some fungal chitosans. Bioscience, Biotechnology and Biochemistry, 56: 1901-1905, 1992.

10. Muzzarelli, R.A.A. Chitin. New York: Peramon Press, 1977.

11. Rane, K.D.; Hoover, D.G. Production of Chitosan by Fungi. Food Biotechnology. 7: 11-33, 1993.

12. Richardson, S.C.; Kolbe, H.V.; Duncan, R. Potential of low molecular mass chitosan as a DNA delivery system: biocompatibility, body distribution and ability to complex and protect DNA. Int. J. Pharm. 178: 231-43, 1999.

13. Roberts, G.A.F. Chitin Chemistry, ed. G.A.E. Roberts, Macmillan Press, Ltd, London, pp. 85-91, 1992.

14. Shimahara, K.; Takiguchi, Y.; Kobayashi, T.; Uda, K.; Sannan, T. Screening of mucoraceae strains suitable for chitosan production. In chitin and Chitosan, ed. G. Skjak-Braek, T. Anthonsen; P. Sandford. Elsevier Appl. Sci. London-New York, pp. 319-322, 1989.

15. Synowiecki, J.; Al-Khateeb, N.A.A.Q. Mycelia of Mucor rouxii as a source of chitin and chitosan. Food Chemistry. 60: 605-610, 1997.

16. Tan, S.C.; Tan, T.K.; Wong, S.M.; Khor, E. The chitosan yield of zygomycetes at their optimum harvesting time. Carbohydrate Polymers 30: 239-242, 1996.

17. Uchegbu, I.F.; Schatzlein, A.G.; Tetley, L.; Gray, A.I.; Sludden, J.; Siddique, S.; Mosha, E. Polymeric chitosan-based vesicles for drug delivery. J. Pharm. Pharmacol. 50: 453-458, 1998.

18. White, S.A.; Farina, P.R.; Fulton, I. Production and Isolation of Chitosan from Mucor rouxii. Applied and Environmental Microbiology. 38: 323 328, 1979. 